\title{
Improving zinc bioavailability in transition from flooded to aerobic rice. A review
}

\author{
Xiaopeng Gao • Ellis Hoffland • TjeerdJan Stomph • \\ Cynthia A. Grant $\cdot$ Chunqin Zou $\cdot$ Fusuo Zhang
}

Accepted: 19 July 2011 /Published online: 9 September 2011

(C) INRA and Springer Science+Business Media B.V. 2011

\begin{abstract}
Zinc ( $\mathrm{Zn}$ ) deficiency is a widely occurring constraint for rice production and for human nutrition. Scarcity of water is leading to a shift from flooded to aerobic rice production, which can have an impact on $\mathrm{Zn}$ deficiency in rice. Zinc bioavailability is a function of both soil and plant factors that can be altered by water management, particularly in relation to conditions in the rhizosphere. Biogeochemical modeling based on bulk soil conditions failed to predict the effect of water management on $\mathrm{Zn}$ bioavailability, but revealed that dissolved organic anions, $\mathrm{pH}$, and redox conditions were major determinants. Rhizosphere sampling is needed to understand the difference in $\mathrm{Zn}$ mobilization and uptake between flooded and aerobic cultivation systems. Zinc bioavailability is not only affected by changes in the chemical properties of the soils, but also by biological processes such as mycorrhizal inoculation and root release of organic compounds into
\end{abstract}

\footnotetext{
X. Gao $(\bowtie) \cdot$ C. A. Grant

Agriculture and Agri-Food Canada, Brandon Research Centre, Box 1000A, R.R.\#3, Brandon, MB, Canada R7A 5Y3

e-mail: xiaopeng.gao@agr.gc.ca

E. Hoffland

Department of Soil Quality, Wageningen University,

PO Box 47, 6700 AA Wageningen, The Netherlands

T. Stomph

Centre for Crop Systems Analysis, Wageningen University,

PO Box 430, 6700 AK Wageningen, The Netherlands

C. Zou $\cdot$ F. Zhang

Key Laboratory of Plant-Soil Interactions, MOE; Key Laboratory of Plant Nutrition and Nutrient Cycling, MOA; Department of Plant Nutrition,

China Agricultural University,

Beijing 100193, China
}

rhizosphere. Phytosiderophores and organic acids are two classes of $\mathrm{Zn}$ chelators secreted from roots that have been linked to the release of $\mathrm{Zn}$ from soil-bound forms and its subsequent uptake by plants. A shift to aerobic condition provides a favorable environment for activity of mycorrhizal fungi and enhanced mycorrhizal inoculation under aerobic conditions has been shown to increase plant $\mathrm{Zn}$ uptake. Aerobic rice genotypes with varying tolerance to $\mathrm{Zn}$ deficiency display a trade-off between mycorrhizal $\mathrm{Zn}$ responsiveness and root exudation of $\mathrm{Zn}$ chelator in the rhizosphere, which is probably due to a competition for carbon. Potential agronomic management practices in aerobic rice production systems are discussed, with an emphasis on their roles in improving bioavailability of $\mathrm{Zn}$. Addition of $\mathrm{Zn}$ fertilizers by soil or foliar application have been shown to increase $\mathrm{Zn}$ concentration in cereal grains but the extent of the increase differs among crop species. The shift from flooded to aerobic condition can cause significant $\mathrm{N}$ transformations, which may consequently affect $\mathrm{Zn}$ mobilization and uptake. An appropriate $\mathrm{N}$ management strategy, including an effective combination of source, rate, application method, and timing, should consider the effects on soil $\mathrm{pH}$. Application of $\mathrm{P}$ fertilizer should be done with careful consideration to the effect on $\mathrm{Zn}$ uptake. A reasonable cropping system (intercropping and crop rotation) could prevent $\mathrm{Zn}$ deficiency and offer an effective and sustainable pathway to $\mathrm{Zn}$ biofortification. Keeping these points in mind, this review describes our current knowledge of $\mathrm{Zn}$ bioavailability as affected by changes in soil-plant interactions caused by the transition from flooded to aerobic rice cultivation.

Keywords Aerobic rice - Arbuscular mycorrhiza . Biofortification $\cdot$ Rhizosphere $\cdot$ Soil $\cdot$ Zinc 


\section{Contents}

1. Introduction . . . . . . . . . . . . . . 2

2. Soil chemical and biological processes. . . . . . . . 3

3. Rhizosphere processes . . . . . . . . . . . . . 4

4. Root growth and mycorrhizal colonization ...... 5

4.1. Role of root growth ... . . . . . . . . . . 5

4.2. Role of mycorrhizae . . . . . . . . . . . . . 6

5. Tolerance to low soil $\mathrm{Zn}$ concentrations in aerobic rice ...................... 6 6. Agronomic options to improve plant $\mathrm{Zn}$ nutrition . . 7

6.1. Zinc fertilization . . . . . . . . . . . . 7

6.2. Nitrogen fertilization . . . . . . . . . . . 7

6.3. Phosphorus fertilization . . . . . . . . . . 8

6.4. Manure application . . . . . . . . . . . . 8

6.5. Intercropping and crop rotation. . . . . . . . . 9

6.6. Tillage. . . . . . . . . . . . . . . 9

7. Possible breeding targets ............ 9

8. Concluding remarks. . . . . . . . . . . . . 10

9. References .................... 11

\section{Introduction}

This review seeks to give an integrated analysis of two important concerns related to sustainable development in rice crop production. These are zinc $(\mathrm{Zn})$ nutrition and the transition from flooded (anaerobic) rice production to irrigated dry land production (aerobic) of rice as advocated for areas where water shortages are of concern (Bouman et al. 2007). Zinc plays a role both in determining human health and in crop productivity in areas where aerobic rice is advocated. Zinc deficiency in crops is widespread, largely reflecting the regions of low $\mathrm{Zn}$ availability in soils and crops (Alloway 2004). Zinc deficiency in humans is prevalent especially in developing conditions where nondiverse diets are composed primarily of cereals that contain a low $\mathrm{Zn}$ concentration with only a small fraction easily absorbed by the gut (Maret and Sandstead 2006). Biofortification of $\mathrm{Zn}$ in staple food crops such as rice can be achieved through conventional breeding, use of genetic modifications, and/or use of agronomic practices, and is considered a promising and cost-effective approach to combat malnutrition (Hotz 2009). The efficacy of this approach has been supported by recent research in Bangladesh where $\mathrm{Zn}$ biofortification in rice substantially decreased $\mathrm{Zn}$ deficiency in human body by improving $\mathrm{Zn}$ adequacy in the daily diet (Arsenault et al. 2010).

Rice is one of the major staple crops worldwide and about $92 \%$ of the world's rice is produced and consumed in Asia (IRRI 1997). Traditionally, about $75 \%$ of rice is produced under flooded (anaerobic) conditions. In many agricultural regions where fresh-water resources are scarce, the traditional lowland system with flooded fields is being replaced by an aerobic system (Fig. 1). The distinguishing feature of aerobic production systems is that crops are direct seeded in freedraining, nonpuddled soils where no standing-water layer is maintained in the field, and roots grow in a mainly aerobic environment (Bouman et al. 2007). Farmers in the North China Plain grow aerobic rice varieties on some 190,000 ha, with an estimated yield potential of 6-7 tha ${ }^{-1}$ (Wang et al. 2002; Bouman et al. 2007). Cropping systems based on aerobic rice are grown commercially in Brazil (Pinheiro et al. 2006). Aerobic rice production is also being intensively studied in Japan, India, Australia, and parts of Southeast Asia and Africa (Bouman et al. 2007). The new cultivation system required the development of suitable aerobic rice cultivars by crossing lowland with upland varieties. Ongoing research on production systems for aerobic rice has mainly focused on the water and nutrient use and yield potential of the aerobic rice cultivars (Belder et al. 2004; Yang et al. 2005; Matsuo et al. 2010; Kato et al. 2011).

Zinc deficiency is frequently reported not only in traditional lowland rice (Dobermann and Fairhust 2000), but also in upland or aerobic rice production, such as on Oxisols and Ultisols in Brazil (Fageria 2000), and on calcareous soils in China (Gao et al. 2006). Zinc solubility and availability to plants differs between flooded soils and aerobic soils. If the conversion of flooded to aerobic rice production occurs in areas where $\mathrm{Zn}$ availability to the crop is likely to be at risk, there is a danger of reducing productivity not only because of less available water but also because of $\mathrm{Zn}$ deficiency. For example, Giordano and Mortvedt (1974) and Wang et al. (2002) reported that Zndeficiency symptoms were more pronounced in plants grown on aerobic soils as compared to anaerobic soils. An
Fig. 1 Cultivation shift from flooded to aerobic rice production system

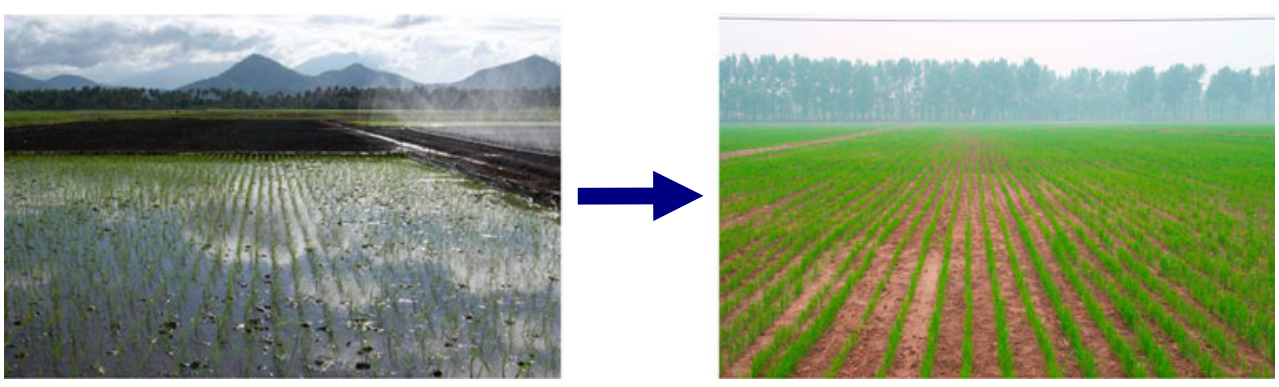


understanding of $\mathrm{Zn}$ behavior in soil and plants under different water regimes is therefore required to assess changes in bioavailability during and after this conversion. In this context, "bioavailability" refers to $\mathrm{Zn}$ availability to the crop, which is usually a small fraction of total soil $\mathrm{Zn}$. Bioavailabilty of $\mathrm{Zn}$ may be reduced to a level where it would not become a direct production constraint to the rice crop, but the grain $\mathrm{Zn}$ concentration may decline, thus compromising nutritional quality.

As a result, the introduction of aerobic rice on low $\mathrm{Zn}$ soils places the problem of $\mathrm{Zn}$ deficiency in rice in a new perspective (Gao et al. 2006). In this article, we review the literature on $\mathrm{Zn}$ bioavailability in rice ecosystems after the transition from flooded to aerobic conditions. We evaluate possible mechanisms explaining the mobilization of $\mathrm{Zn}$ in the soil and the uptake of $\mathrm{Zn}$ by the plant and explore available options for crop management and/or breeding to improve both quantity and nutritional quality of rice produced. The structure of the paper follows the major relevant processes, soil chemical and biological processes (Section 2), root-induced rhizosphere processes (Section 3), adjustments in root growth and mycorrhizal colonization (Section 4), the role and consequence of plant tolerance to low $\mathrm{Zn}$ and grain allocation attributes of rice (Section 5), and finally the agronomic (Section 6) and breeding (Section 7) options to improve plant $\mathrm{Zn}$ nutrition during the shift from flooded to aerobic rice production. The paper then finishes with some concluding remarks indicating what we consider major remaining research issues and considerations for breeding strategies.

\section{Soil chemical and biological processes}

Zinc bioavailability in soils is primarily regulated by adsorption-desorption reactions and solubility relations between the solution and solid phases (Fig. 2). Soil properties including the $\mathrm{pH}$, redox potential, organic matter, pedogenic oxide, and soil sulfur content exert the most significant influence on the adsorption-desorption and dissolution-precipitation reactions of $\mathrm{Zn}$ in soils and thus regulate the amount of $\mathrm{Zn}$ dissolved in the soil solution (Alloway 2009). Some of these factors are expected to change after a shift to aerobic cultivation. Flooding can shift the soil $\mathrm{pH}$ towards neutral, so aerobic production can cause the $\mathrm{pH}$ of the bulk soil to revert toward the original soil pH (Ponnamperuma 1972). The redox potential will increase under aerobic condition (Gao et al. 2002), causing the formation of $\mathrm{Fe}$ and $\mathrm{Mn}$ oxides, onto which $\mathrm{Zn}$ might be adsorbed. Precipitation of $\mathrm{Zn}$ as $\mathrm{ZnS}$ decreases under aerobic conditions (Carbonell-Barrachina et al. 2000). The cultivation shift to aerobic may also lead to an increase in the number and diversity of Fe-oxidizing/reducing bacteria

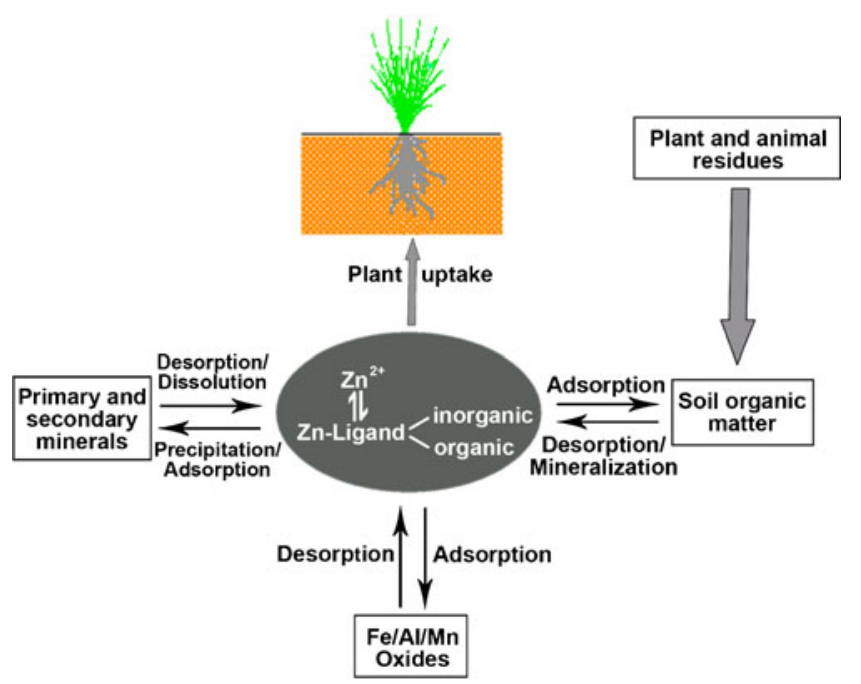

Fig. 2 Soil processes affecting Zn bioavailability in soil solution

(Chen et al. 2008), which may consequently affect concentration and speciation of $\mathrm{Zn}$ in the soil solution. The organic matter content may decrease under aerobic condition because of oxidation. The dominant processes may differ among soils and lead to an apparent disagreement among studies. For instance, while Gao et al. (2006, 2010c) observed in field studies with calcareous soil, that shifting from flooded to aerobic rice caused $\mathrm{Zn}$ deficiency in rice, Johnson-Beebout et al. (2009) reported in a pot study also with a calcareous soil that both soil-available $\mathrm{Zn}$ and plant $\mathrm{Zn}$ uptake increased with the oxidized soil treatment compared with flooding. The apparently contrasting results could be due to the difference in soil sulfur content and achievable redox conditions in the two studies. In the flooded treatment in the field studies by Gao et al. (2010c), precipitation of $\mathrm{ZnS}$ was not expected because the soil redox potential never got as negative as the level required for the formation of $\mathrm{ZnS}$. In contrast, the decreased $\mathrm{Zn}$ availability upon flooding in the pot study by JohnsonBeebout et al. (2009) coincided with a very low redox. Several other factors such as soil $\mathrm{pH}$ could also have a dominant impact. For example, whether the transition to aerobic rice occurs on alkaline or acid soils may lead to a contrasting effect on $\mathrm{Zn}$ bioavailability because of the change in soil $\mathrm{pH}$. These combined observations have important implications for water management of rice on different soil types.

In a number of field experiments at different locations in China over different years, Zn bioavailability was lower in aerobic as compared to flooded rice cultivation systems, as indicated by reduced $\mathrm{Zn}$ concentration in plant tissue, $\mathrm{Zn}$ uptake and $\mathrm{Zn}$ harvest index (Gao et al. 2006, 2010c; Table 1). A biogeochemical modeling based on bulk soil conditions revealed that soil acidity, dissolved organic carbon (DOC), and redox condition were important 
Table 1 Concentration and accumulation of $\mathrm{Zn}$ in rice grown under flooded and aerobic conditions in two experimental sites

\begin{tabular}{|c|c|c|c|c|c|c|}
\hline & \multicolumn{2}{|c|}{$\mathrm{Zn}$ concentration $\left(\mathrm{mg} \mathrm{kg}^{-1}\right)$} & \multicolumn{2}{|c|}{$\mathrm{Zn}$ accumulation $\left(\mathrm{g} \mathrm{ha}^{-1}\right)$} & \multicolumn{2}{|c|}{ Harvest index $(\%)$} \\
\hline & Shoot & Grain & Shoot & Grain & Biomass & $\mathrm{Zn}$ \\
\hline \multicolumn{7}{|l|}{ Site A } \\
\hline Flooded & $28.7 \mathrm{a}$ & $25.0 \mathrm{a}$ & $170 \mathrm{a}$ & $158 \mathrm{a}$ & $51 \mathrm{a}$ & $48 \mathrm{a}$ \\
\hline Aerobic & $20.4 \mathrm{~b}$ & $24.5 \mathrm{a}$ & $125 \mathrm{~b}$ & $67 \mathrm{~b}$ & $32 \mathrm{~b}$ & $35 \mathrm{~b}$ \\
\hline \multicolumn{7}{|l|}{ Site B } \\
\hline Flooded & $14.1 \mathrm{a}$ & $18.4 \mathrm{a}$ & $255 \mathrm{a}$ & $94 \mathrm{a}$ & $31 \mathrm{a}$ & $27 \mathrm{a}$ \\
\hline Aerobic & $11.0 \mathrm{~b}$ & $16.3 \mathrm{~b}$ & $222 \mathrm{~b}$ & $75 \mathrm{~b}$ & $30 \mathrm{a}$ & $24 \mathrm{~b}$ \\
\hline
\end{tabular}

Grain $\mathrm{Zn}$ concentration refers to the whole grain data in site A while the brown rice data in site B

Biomass harvest index $=$ grain yield $/($ grain yield + shoot biomass $)$

Zinc harvest index $=$ grain $\mathrm{Zn}$ accumulation/(shoot+ grain $\mathrm{Zn}$ accumulation)

Within site, per column means followed by the same letter are not significantly different (Tukey, $P=0.05$ ).

Sources: Gao et al. $(2006,2010$ c)

determinants of $\mathrm{Zn}$ availability in soil but failed to predict the effect of water management on $\mathrm{Zn}$ bioavailability as indicated by Zn uptake (Gao et al. 2010c). Difference in plant $\mathrm{Zn}$ uptake between two cultivation systems was only $15 \%$, a much lower value than the orders of magnitude difference in soil $\mathrm{Zn}$ concentration predicted by modeling. The difference between the experimental observations and the model calculation was associated with the chemical conditions in the rhizosphere, where the local acidity, dissolved organic $\mathrm{C}$, and redox conditions may deviate significantly from the bulk soil on which the geochemical analysis was based (Gao et al. 2010c). An unbiased rhizosphere sampling is therefore needed to better understand the difference in $\mathrm{Zn}$ mobilization and uptake between the two cultivation systems. The modeling results revealed that the root-induced changes in chemical properties in the rhizosphere compared to the bulk of the soil must be considered when comparing the two cultivation systems.

The different rates in transpiration and diffusion between aerobic and flooded fields might also have a significant impact on crop $\mathrm{Zn}$ uptake. In aerobic fields, low rates of dissolution and diffusion of $\mathrm{Zn}$ in soils may restrict $\mathrm{Zn}$ transport towards the plant root (Yoshida 1981). A lower transpiration rate in aerobic than flooded fields may also decrease the mass flow of $\mathrm{Zn}$ from soil to plants and consequently decrease $\mathrm{Zn}$ uptake by plants, as well as the allocation to the grain.

\section{Rhizosphere processes}

Major mechanisms increasing $\mathrm{Zn}$ acquisition by plant roots include (1) the increase of acquisition area by root growth or the involvement of mycorrhizae (see Section 4), and (2) root-induced chemical changes in the rhizosphere, specif- ically the changes in rhizosphere $\mathrm{pH}$ and root exudation of organic acids or phytosiderophores (Fig. 3).

Root-induced changes in the rhizosphere $\mathrm{pH}$ and release of low and high molecular weight exudates are of major importance for $\mathrm{Zn}$ acquisition by crops grown on low $\mathrm{Zn}$ soils. In lowland rice, rhizosphere acidification can enhance the utilization of not only P (Kirk and Saleque 1995) but also Zn (Kirk and Bajita 1995). The excretion of organic acids or phytosiderophores capable of increasing the bioavailability of $\mathrm{Zn}$ in the rhizosphere is a potential mechanism of reducing $\mathrm{Zn}$ deficiency in lowland rice.

Changes in rhizosphere $\mathrm{pH}$ are the result of the excretion of protons $\left(\mathrm{H}^{+}\right)$and hydroxyl $\left(\mathrm{OH}^{-}\right)$or bicarbonate $\left(\mathrm{HCO}_{3}{ }^{-}\right)$ions due to a cation-anion imbalance in the plant, the evolution of $\mathrm{CO}_{2}$ by respiration, and the excretion of low-molecular-weight organic acids (LMWOAs). The form of nitrogen $(\mathrm{N})$ supply has the most prominent influence on cation/anion uptake ratio, and thus on rhizosphere $\mathrm{pH}$

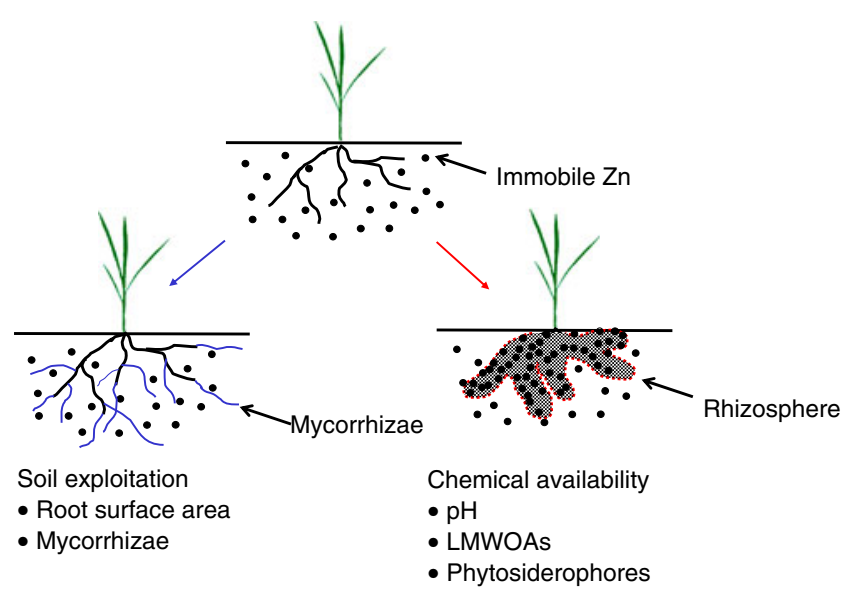

Fig. 3 Plant factors affecting $\mathrm{Zn}$ uptake by plants (LMWOAs lowmolecular-weight organic acids) 
(Marschner 1995). When grown in an anaerobic soil, $\mathrm{O}_{2}$ released from the roots could lead to higher $\mathrm{H}^{+}$extrusion and to an increase in $\mathrm{Zn}$ bioavailability for plants (Kirk and Bajita 1995). Also, rice roots take up $\mathrm{N}$ primarily as $\mathrm{NH}_{4}{ }^{+}$, resulting in a release of $\mathrm{H}^{+}$by roots and a consequent decrease in rhizosphere $\mathrm{pH}$. In the case of aerobic rice cultivation, the shift of the dominant form of $\mathrm{N}$ uptake from $\mathrm{NH}_{4}{ }^{+}$to $\mathrm{NO}_{3}{ }^{-}$is expected to lead to exudation of $\mathrm{OH}^{-}$into the rhizosphere resulting in an increase in rhizosphere $\mathrm{pH}$ with a subsequent reduction in $\mathrm{Zn}$ availability. The shift in rhizosphere $\mathrm{pH}$ as a result of changing $\mathrm{N}$ dynamics may be the cause of the reduced $\mathrm{Zn}$ uptake observed in rice grown in aerobic fields compared to flooded fields on a calcareous soil (Gao et al. 2006).

Lowland rice can exude LMWOAs, with exudation rates being affected by experimental conditions. For example, lowland rice increased malate exudation in response to higher bicarbonate levels in the root growth medium (Yang et al. 2003; Hajiboland et al. 2005). Under Zn deficiency, lowland rice increased citric acid exudation and it was suggested that the citrate exudation capacity of rice genotypes was related to their tolerance to $\mathrm{Zn}$ deficiency (Hoffland et al. 2006). In aerobic rice, malate exudation was detected under both soil and hydroponic conditions with the malate concentration in the rhizosphere being approximately $0.5 \mathrm{mM}$ (Gao et al. 2009). The exudation rate was increased by $\mathrm{Zn}$ deficiency in either experiment although subsequent soil extraction experiments found that malate was unable to solubilise significant amounts of $\mathrm{Zn}$ from the soil. This conclusion was confirmed by a recent study by Rose et al. (2011), in which it was found that malate concentrations in the soil solution needs to be higher than $100 \mathrm{mM}$ to exert significant $\mathrm{Zn}$ mobilization. Therefore, mechanisms other than LMWOAs exudation are probably of more importance for $\mathrm{Zn}$ mobilization by aerobic rice genotypes. This conclusion was confirmed by the recent work of Arnold et al. (2010), in which they used the isotope fractionation technology and a mathematical model to show that the release of phytosiderophores is the major mechanism explaining differences in $\mathrm{Zn}$ uptake by rice genotypes with varying uptake efficiency.

A number of studies on root-induced chemical changes in the rhizosphere focused on the release of phytosiderophores. Durum wheat genotypes that were sensitive to $\mathrm{Zn}$ deficiency exuded smaller amounts of phytosiderophores than bread wheat genotypes that were tolerant of $\mathrm{Zn}$ deficiency in a nutrient solution experiment (Walter et al. 1994). Zinc deficiency increases the secretion of phytosiderophores from wheat (Cakmak et al. 1994) and barley (Suzuki et al. 2006) roots into the rhizosphere. Unlike most graminaceous crops, rice is well adapted to growth under submerged conditions and releases smaller amounts of phytosiderophores than other crops (Takagi 1976). None- theless, the release of phytosiderophores has been shown to be essential for $\mathrm{Fe}$ uptake by rice seedlings in aerobic soils (Inoue et al. 2009), as well as Zn uptake by rice grown in submerged soils (Arnold et al. 2010). In contrast, Suzuki et al. (2008) found that $\mathrm{Fe}$ deficiency, not $\mathrm{Zn}$ deficiency, induced greater phytosiderophores secretion by rice roots and suggested a limited role of phytosiderophores in $\mathrm{Zn}$ deficient rice. The mechanisms to explain the differential results remain unclear but are presumably related to the rice genotypes (japonica vs. indicas) or growth conditions (soil vs. hydroponic) used in the studies. Reports that directly compare root exudation between flooded and nonflooded conditions and the consequent effect on $\mathrm{Zn}$ availability to rice plants are still lacking. It is, however, reasonable to expect a greater impact of phytosiderophores under aerobic than flooded conditions. Under aerobic conditions, transport of exudates away from the roots is slowed and exudate concentrations at the root surface are therefore increased because of the accumulation effect. A detailed understanding of mechanism for the release of phytosiderophores by rice roots and their subsequent effects on plant $\mathrm{Zn}$ uptake requires further investigation.

\section{Root growth and mycorrhizal colonization}

\subsection{Role of root growth}

Generally, healthy root growth producing a large absorbing surface and the ability to explore undepleted soil horizons is the basis for highly efficient nutrient and water acquisition. Aerobic rice cultivars need to have a deeper rooting and a higher root length density than lowland rice cultivars because of the limited water availability under aerobic as compared to flooded conditions (Matsuo et al. 2010).

On calcareous soils, where the major shift to aerobic rice cultivation is taking place in China (Wang et al. 2002), Zn deficiency typically coincides with high bicarbonate levels in the soil solution. In such areas, maintaining good root growth is particularly important in that it can increase the tolerance not only to low $\mathrm{Zn}$ bioavailability, but also to the high bicarbonate concentration in soil (Yang et al. 1994; Hajiboland et al. 2005; Ismail et al. 2007).

Better understanding of the regulation of root growth can help to develop better management strategies in agricultural production. Reviews on regulation of root growth are available (Forde and Lorenzo 2001). Two major strategies proposed to control root development of crops are use of new varieties with efficient root traits and application of directional rhizosphere management such as localized nutrient/water supply (Zhang et al. 2010). These two strategies can also be applied during the transition from flooded to aerobic rice cultivation. First, new aerobic rice 
varieties should be developed with root growth adapted to aerobic condition. Secondly, concentrated placement of fertilizers could be used to enhance uptake as the number of lateral roots developed on parent roots will be greatly stimulated by the localized supply of high nitrate or phosphate in crops (Drew and Saker 1975, 1978). Localized supply of $\mathrm{NO}_{3}{ }^{-}$can stimulate Arabidopsis lateral root elongation by two to three fold (Zhang et al. 1999). Similar results were also found on the $\mathrm{Zn}$ hyperaccumulator species Thlaspi caerulescens, where in a split-root system, roots exposed to soil enriched with $\mathrm{Zn}$ produced higher biomass and length than the roots exposed to unenriched soil (Whiting et al. 2000). In intensive Chinese agricultural practices including the new aerobic rice system, localized application of $\mathrm{N}$ and $\mathrm{P}$ fertilizers has been recommended and led to higher nutrient use efficiency through improved root growth of crops (Zhang et al. 2010). This is especially important at the early growth stages in rice production, when $\mathrm{Zn}$ deficiency was found to be more pronounced (Dobermann and Fairhust 2000).

\subsection{Role of mycorrhizae}

A large number of studies demonstrate the beneficial effect of AM fungi on $\mathrm{Zn}$ uptake by the host plants, including lowland rice (Purakayastha and Chhonkar 2001), pigeon pea (Wellings et al. 1991), wheat (Ryan and Angus 2003), and tomato (Cavagnaro et al. 2010). The effects are mostly reported for plants grown in soils with low $\mathrm{Zn}$ availability. Cavagnaro (2008) thoroughly reviewed the role of arbuscular mycorrhizae in improving $\mathrm{Zn}$ acquisition by plants on low $\mathrm{Zn}$ soils and concluded that improvements in the $\mathrm{Zn}$ nutrition of plants colonized by AMF can be attributed to direct uptake of $\mathrm{Zn}$ by AMF, and/or indirect effects brought about by morphological and physiological changes in roots due to colonization by AMF.

While mycorrhizal fungi can survive in flooded conditions (Purakayastha and Chhonkar 2001), the shift to aerobic conditions will provide a more favorable environment for their activity. In a pot study by Hajiboland et al. (2009), rice plants were inoculated with Glomus mosseae or Glomus intraradices in nonflooded nurseries and then transplanted either to flooded or nonflooded $(60 \%$ of water holding capacity) conditions. Results showed that root colonization was $43 \%$ under nonflooded compared to $27 \%$ under flooded conditions. In a pot study with six aerobic rice genotypes varying in $\mathrm{Zn}$ uptake efficiency grown aerobically on a low $\mathrm{Zn}$ soil, Gao et al. (2007) observed a relatively high root colonization by AM fungi (28-57\% depending on genotypes) and a significant effect on $\mathrm{Zn}$ uptake. The increase in $\mathrm{Zn}$ uptake by AM fungi, however, was only significant in genotypes with a low inherent $\mathrm{Zn}$ uptake when nonmycorrhizal, indicating a trade-off between the positive effects from AM fungi and inherent uptake capacity, which was mostly associated with root-induced rhizosphere processes such as exudation of $\mathrm{Zn}$ chelators. The results suggest that plants that show high response to mycorrhizal fungi have a lower capability of mobilizing $\mathrm{Zn}$ from low $\mathrm{Zn}$ soils. The competition for carbon between the processes involved in production of $\mathrm{Zn}$ chelators and the mycorrhizal fungi is likely to explain the observed trade-off.

\section{Tolerance to low soil $\mathrm{Zn}$ concentrations in aerobic rice}

Aerobic rice cultivars developed by crossing lowland with upland varieties, exhibit significant genotypic variation in tolerance to low soil $\mathrm{Zn}$ (Gao et al. 2005), as has been reported for lowland rice (Wissuwa et al. 2006; Chen et al. 2009) and for other crop species including maize (Ramani and Kannan 1985), wheat (Cakmak et al. 2004), common bean (Hacisalihoglu et al. 2004), and barley (Genc et al. 2004). This genotypic variation could be exploited in breeding programs to produce genotypes which are adapted to low $\mathrm{Zn}$ soils.

Numerous studies have been conducted to investigate the mechanisms for tolerance to $\mathrm{Zn}$ deficiency in rice, which include increased $\mathrm{Zn}$ uptake by plant roots (Gao et al. 2005; Wissuwa et al. 2006), enhanced translocation of $\mathrm{Zn}$ from roots to shoots (Gao et al. 2005), and/or more efficient internal utilization of $\mathrm{Zn}$ in plant cells (Chen et al. 2009). The relative contribution of each mechanism may differ depending on the cultivars and growing environment. For example, when comparing two lowland rice cultivars with contrasting tolerance to $\mathrm{Zn}$ deficiency in a nutrient solution experiment that reduced possible uptake differences, Chen et al. (2009) found that the efficient genotype was more efficient in internal utilization of $\mathrm{Zn}$; specifically a higher antioxidative enzyme activity was observed per amount of $\mathrm{Zn}$ in the plant tissue. In contrast, in a field study with ten lowland rice genotypes grown on a permanently flooded low Zn soil, Wissuwa et al. (2006) concluded that rhizosphere processes that enhance availability and uptake of $\mathrm{Zn}$ were of higher importance than differences in internal use. In line with the study on lowland rice by Wissuwa et al. (2006), plant uptake of $\mathrm{Zn}$ was identified as the most important factor determining the ranking of tolerance to $\mathrm{Zn}$ deficiency among 15 aerobic rice genotypes grown on a low $\mathrm{Zn}$ soil in a pot study (Gao et al. 2005). Similar results were also reported in chickpea (Khan et al. 1998), common bean (Hacisalihoglu et al. 2004), and wheat (Genc et al. 2006), where these crops were grown on low $\mathrm{Zn}$ soils. These results lead to a generalization that the primary determinant for tolerance to $\mathrm{Zn}$ deficiency in cereal crops relates to the plant's ability to take up $\mathrm{Zn}$ from the soil. 
Besides the capacity to increase plant $\mathrm{Zn}$ uptake, the tolerant rice genotypes can also accumulate more $\mathrm{Zn}$ in the grain than sensitive ones. In a pot study using the isotope tracer ${ }^{68} \mathrm{Zn}$, an efficient (based on dry matter production) rice genotype allocated more $\mathrm{Zn}$ from leaves and stems to the grain than the inefficient genotype (Wu et al. 2010). This phenomenon was also observed in wheat in a pot study conducted on low $\mathrm{Zn}$ calcareous subsoils from Australia. The tolerant wheat cultivar was not only more efficient in root $\mathrm{Zn}$ uptake, but also sevenfold more efficient than the sensitive cultivar in partitioning $\mathrm{Zn}$ to the grain (Holloway et al. 2010). In contrast, Jiang et al. (2008b) found no correlation between grain yield efficiency and grain $\mathrm{Zn}$ concentration in a comparison of data from two independent experiments with a total of 26 cultivars. The combination of high tolerance to Zn deficiency with high grain $\mathrm{Zn}$ seems a relevant breeding objective and may seem feasible given that some lines showed superior in both aspects.

In the field trials described in Table 1 , grain $\mathrm{Zn}$ concentrations were either reduced or unaffected by the shift to aerobic cultivation. For both conditions, however, concentrations of $\mathrm{Zn}$ in rice grain were low (16-18 $\mathrm{mg} \mathrm{kg}^{-1}$ for brown rice), compared to the recommended target of 40-60 mg kg${ }^{-1}$ for human nutrition (Graham et al. 2007). The $\mathrm{Zn}$ harvest index, which measures the quantity of $\mathrm{Zn}$ translocated to grain relative to the amount of $\mathrm{Zn}$ absorbed by the roots, was also decreased by the cultivation shift to aerobic conditions in two trials, in line with a reduced harvest index (dry matter-based).

\section{Agronomic options to improve plant $\mathrm{Zn}$ nutrition}

\subsection{Zinc fertilization}

Application of $\mathrm{Zn}$ fertilizer is a common agricultural practice in lowland rice production to correct $\mathrm{Zn}$ deficiency and increase grain yield (Dobermann and Fairhust 2000). Under continuously flooded conditions, efficiency of fertilizer $\mathrm{Zn}$ is mainly restricted by precipitation of $\mathrm{ZnS}$ (Ponnamperuma 1972), $\mathrm{ZnCO}_{3}$ (Bostick et al. 2001), and binding to organic matter (Yoshida et al. 1971) in the bulk soil or the precipitation of $\mathrm{Zn}$ with $\mathrm{Fe}$ oxides in the rhizosphere (Sajwan 1985). Therefore, incorporation of $\mathrm{Zn}$ fertilizer into the soil before flooding may be an effective strategy in lowland rice production. With the transition to aerobic conditions, reduction in soil moisture may restrict the diffusion of $\mathrm{Zn}$ to rice roots (Mengel and Kirkby 1987). A localized supply should therefore be recommended under aerobic condition. Seed coating can also be used as an effective way to improve both grain yield and grain $\mathrm{Zn}$ concentration under aerobic condition, as shown in wheat
(Cakmak 2008) and maize (Harris et al. 2007). The management of fertilizer to match the cultivation shift should consider the best combination of placement, time of application, and source and application rate of fertilizers. Little information is available in the literature to aid in the determination of the best management option.

In principle, increased plant $\mathrm{Zn}$ concentration by $\mathrm{Zn}$ fertilizer can lead to increased grain zinc concentration in cereals. In rice, however, there is not a strong positive effect of increased plant $\mathrm{Zn}$ concentration on grain $\mathrm{Zn}$ concentration (Gao et al. 2006; Wissuwa et al. 2007; Jiang et al. 2008a). Jiang et al. (2008a) established in two experiments using a total of four aerobic cultivars that a 20 - to 30 -fold increase in plant shoot $\mathrm{Zn}$ concentration was associated with a two-fold increase in grain $\mathrm{Zn}$ concentration. An increase of this magnitude in plant $\mathrm{Zn}$ concentration could be obtained in nutrient solution culture but could never be reached under field conditions. The work indicated the need to specifically breed for better within-plant allocation of $\mathrm{Zn}$ from the tissue to the grain when plant $\mathrm{Zn}$ concentrations are enhanced. Furthermore, Srivastava et al. (1999) showed that soil $\mathrm{Zn}$ application at transplanting only marginally increased grain $\mathrm{Zn}$ concentration of lowland rice, indicating that while $\mathrm{Zn}$ application at transplanting is effective from a production perspective, it has little benefit in improving the nutritional value of the grain. In contrast to the very limited effect on rice, $\mathrm{Zn}$ applied as a soil or foliar treatment or a combination of both increased grain $\mathrm{Zn}$ concentration of wheat grown on a low $\mathrm{Zn}$ calcareous soil in Turkey by a factor of 3 or more, raising concentration up to $60 \mathrm{mg} \mathrm{Zn} \mathrm{kg}{ }^{-1}$ (Yilmaz et al. 1997).

The difference between the species could be due to species differences in physiological processes determining accumulation of $\mathrm{Zn}$ in the grain. Whether these include a root-shoot barrier and the process of grain filling (Palmgren et al. 2008), or mainly limited movement during grain filling and stem-panicle transfer (Jiang et al. 2008a; Stomph et al. 2009) remains to be further clarified in order to provide better breeding targets. Also the role of direct allocation of $\mathrm{Zn}$ from uptake during flowering (Jiang et al. 2007) versus re-allocation of previously stored $\mathrm{Zn}$ needs further clarification. Regardless, plant $\mathrm{Zn}$ uptake should be improved and possibly maintained longer to increase the nutritional quality of the grain, while adoption of aerobic growing conditions would likely lead to reduced rather than increased grain $\mathrm{Zn}$ concentration.

\subsection{Nitrogen fertilization}

The cultivation shift from flooded to aerobic in rice production will be linked to changes in management practices for fertilizer $\mathrm{N}$, which may exert a significant influence on bioavailability of $\mathrm{Zn}$. Under flooded condi- 
tions, use of urea or ammonium-based fertilizer is more effective than use of nitrate containing fertilizers in reducing $\mathrm{N}$ loss (Broadbent and Mikkelsen 1968). The effect of $\mathrm{NH}_{4}-\mathrm{N}$ on decreasing rhizosphere $\mathrm{pH}$ has already been mentioned. In addition, the formation of $\mathrm{Zn}-\mathrm{NH}_{3}$ complexes could directly increase the solubility of $\mathrm{Zn}$ at high soil $\mathrm{pH}$ levels (Lindsay 1972). The soil aeration resulting from the transition to aerobic rice will promote the formation of $\mathrm{NO}_{3}{ }^{-}$via nitrification of indigenous soil $\mathrm{N}$ and fertilizer $\mathrm{N}$. Accumulated soil $\mathrm{NO}_{3}{ }^{-}$can lead to an increase in rhizosphere $\mathrm{pH}$ and consequently a reduced bioavailability of $\mathrm{Zn}$ to rice crops on calcareous soils. Selection of suitable source of $\mathrm{N}$ fertilizer based on the soil properties is therefore important. Application of ammonium sulfate can have a significantly acidifying effect on soils and so lead to an increase in the availability of $\mathrm{Zn}$ to crops in soils of relatively high $\mathrm{pH}$ status. Conversely, calcium nitrate can increase the soil $\mathrm{pH}$ and reduce $\mathrm{Zn}$ availability (Alloway 2004). Nitrogen fertilizers can also increase $\mathrm{Zn}$ uptake of crops by promotion of plant and root growth (Giordano 1979). Because of the relatively new concept of aerobic rice production, an appropriate $\mathrm{N}$ management strategy is yet to be established.

While $\mathrm{N}$ appears to play a critical role in the uptake and accumulation of $\mathrm{Zn}$ in plants, the effect of $\mathrm{N}$ fertilization on $\mathrm{Zn}$ concentration in crop grain, especially under field conditions is ambiguous. Effect of $\mathrm{N}$ fertilizers on crop grain $\mathrm{Zn}$ concentration has been shown to be positive (Kutman et al. 2010; Shi et al. 2010), negative (Zhang et al. 2008; Gao et al. 2010b) or absent (Moraghan et al. 1999). The mechanism for seemingly conflicting findings on $\mathrm{N}-$ $\mathrm{Zn}$ relationships remains unknown but is presumably related to soil type, plant-available soil $\mathrm{Zn}$, plant genotypic differences in uptake and translocation of $\mathrm{Zn}$ in crops, the application rate of $\mathrm{N}$ fertilization and the effect of $\mathrm{N}$ on crop yield. Effects will depend on whether the dilution caused by increased grain yield in response to $\mathrm{N}$ application is compensated for by an increased ability of the crop to access and accumulate $\mathrm{Zn}$ from the soil. Recent literature indicates that a sufficiently high rate of $\mathrm{N}$ application is effective in enhancing grain $\mathrm{Zn}$ in crops, especially on a soil naturally high in plant-available $\mathrm{Zn}$ or when plant $\mathrm{Zn}$ nutrition is sufficient through foliar $\mathrm{Zn}$ application (Cakmak et al. 2010; Kutman et al. 2010; Erenoglu et al. 2011). Because most soils being proposed for the rice cultivation shift in China are calcareous and are generally deficient in both available $\mathrm{N}$ and available $\mathrm{Zn}$, a relatively high rate of $\mathrm{N}$ application and its potential role on improving grain $\mathrm{Zn}$ in rice is also expected.

\subsection{Phosphorus fertilization}

The shift from flooded to aerobic condition decreases availability and uptake of both native soil $\mathrm{P}$ and applied $\mathrm{P}$, due to the decrease in soil $\mathrm{P}$ diffusion and increase in $\mathrm{P}$ sorption on metal oxides (Yadvinder et al. 2000). Hence, the application of fertilizer P can be more critical for aerobic rice than for conventional flooded lowland rice. To our knowledge, however, the response of $\mathrm{Zn}$ bioavailability of aerobic rice to $P$ fertilizers has not yet been reported.

Development of $\mathrm{Zn}$ deficiency following $\mathrm{P}$ fertilization is known as a P-induced inhibition of $\mathrm{Zn}$ accumulation. Various hypotheses have been proposed to explain the interaction, including (1) $\mathrm{P}-\mathrm{Zn}$ interaction in the soil (Agbenin 1998), (2) less translocation of $\mathrm{Zn}$ from the roots to the shoots (Olsen 1972; Verna and Minhas 1987), (3) metabolic disorder within plant cell (Haldar and Mandal 1981), and (4) dilution (Olsen 1972). Under field conditions, the effect of $\mathrm{P}$ fertilization on $\mathrm{Zn}$ concentration in crop grain has been found to be additive, antagonistic, or nonexistent, depending on the experimental conditions. For example, in a 3-year field experiment performed in Manitoba Canada, phosphate fertilization as monoammonium phosphate at $13 \mathrm{~kg} \mathrm{Pha}^{-1}$ did not affect $\mathrm{Zn}$ concentration in grain of durum wheat (Gao et al. 2010a). Similar results were also reported in lowland rice (Fageria and Filho 2007). In contrast, Grant et al. $(2002,2010)$ found phosphate fertilization in most site-years decreased grain $\mathrm{Zn}$ concentration of durum wheat grown at various locations in Canada, possibly due to a reduction in vesicular arbuscular mycorrhizal infection.

\subsection{Manure application}

Manure application contributes to $\mathrm{Zn}$ accumulation in crops both through direct addition of $\mathrm{Zn}$ and mobilization of $\mathrm{Zn}$ already present in the soil. Twenty-five continuous annual applications of cattle manure under irrigated conditions increased not only the total $\mathrm{Zn}$ concentration, but also EDTA-extractable Zn concentration in southern Alberta in Canada, possibly due to the increased formation of soluble dissolved organic carbon (DOC)-Zn complexes (Benke et al. 2008). In a pot trial, application of poultry and piggery manures at the rate of 10 tha $^{-1}$ increased the yield and uptake of $\mathrm{Zn}$ by wheat (Gupta et al. 1992). In a rice-wheat rotation, manure application maintained a higher soilavailable $\mathrm{Zn}$ compared to inorganic fertilizers (Alok and Yadav 1995). Similarly, Egrinya et al. (2001) found a positive effect of animal manure on $\mathrm{Zn}$ availability in soils. Application of manure can affect soil properties which may influence $\mathrm{Zn}$ in soil and crop uptake. The $\mathrm{N}$ and organic acids of the manure may decrease soil $\mathrm{pH}$ and mobilize $\mathrm{Zn}$ already present in the soil, but insoluble organic complexes also may form as the manure decomposes, binding $\mathrm{Zn}$ and reducing its availability for plant uptake. Therefore, the effect of manure on $\mathrm{Zn}$ bioavailability depends on the characteristics of the manure and on the specific circum- 
stances involved. Studies on the effect of manure on micronutrient bioavailability in cereal grain are too rare to support a conclusion.

\subsection{Intercropping and crop rotation}

Transition from flooded to aerobic rice cultivation has made it possible to intercrop rice together with other plants. Intercropping of aerobic rice with peanut and watermelon has been practiced in some areas of China and has shown benefits on $\mathrm{N}$ fixation (Shen and $\mathrm{Chu} 2004$ ) and disease control (Ren et al. 2008). So far, however, no studies have addressed alleviation of $\mathrm{Zn}$ deficiency by intercropping in aerobic rice cultivation. In a Chinese peanut/maize intercropping example, the excretion of phytosiderophores by maize into the rhizosphere played an important role in improving $\mathrm{Fe}$ and $\mathrm{Zn}$ nutrition of the peanut crop (Zuo and Zhang 2008). Similarly, Inal et al. (2007) and Inal and Gunes (2008) observed an improvement in Fe nutrition of peanut intercropped with maize, which was attributed to the higher Fe-solubilizing activity (Fe-SA) and ferric reducing (FR) capacity in the mixed culture. These results indicate the importance of intercropping systems as a promising management practice to alleviate $\mathrm{Zn}$ and Fe deficiency stress and a potential option for micronutrient biofortification. Recently, Zuo and Zhang (2009) thoroughly reviewed the potential role of intercropping dicot plants with gramineous species in $\mathrm{Fe}$ and $\mathrm{Zn}$ biofortification and suggested that intercropping is a practical, effective, and sustainable practice in developing countries. Not only the dicot crop, but also the graminaceous crop can receive benefits from intercropping system. For instance, in a field experiment conducted on a low $\mathrm{Zn}$ soil in Turkey, $\mathrm{Zn}$ concentrations in both wheat and chickpea was higher in the intercropped system than in the monocropped system (Gunes et al. 2007). Adoption of aerobic rice in the gramineous/dicot intercropping system will add new insights into this subject.

As has been reported in China (Wang et al. 2002) and in Brazil (Pinheiro et al. 2006), aerobic rice yield is significantly reduced after 2 years of consecutive planting on the same area in monoculture. In Brazil, aerobic rice in rotation with soybean is an attractive system, which has shown improvements in crop yield by reducing the incidence of pests and diseases (Pinheiro et al. 2006). Crop rotation is widely reported to affect the growth and yield of crops through improved water use efficiency, soil chemical changes such as acidification, changes in organic carbon content and cation exchange capacity, and reduction in disease, insect, and weed problems. The changes in soil properties may also affect uptake of $\mathrm{Zn}$ by crops. However, results dealing with the effects on $\mathrm{Zn}$ availability to cereal crops, especially $\mathrm{Zn}$ concentration in cereal grain, are relatively rare. On several Indian Alfisols and Inceptisols,
Mandal et al. (2000) found a higher $\mathrm{Zn}$ desorption under alternate flooding-drying condition than in a continuously flooded control, indicating that a flooded rice-maize rotation can use $\mathrm{Zn}$ fertilizer more efficiently than continuously flooded rice. While the impact of crop rotation on biofortification of $\mathrm{Zn}$ in aerobic rice has not yet been studied, some work has suggested that improved grain yield and grain quality could be attained by introduction of a good rotation system (Khoshgoftarmanesh and Chaney 2007; Ryan et al. 2008; Turmel et al. 2009; Grant et al. 2010). For instance, on a P-deficient acidic red loam soil in Australia, Zn concentration in wheat grain was 30-40\% lower for crops following canola and fallow than for those following linola and pasture (Ryan et al. 2008). Similarly, in a 3-year field trial in Manitoba of Canada, grain $\mathrm{Zn}$ concentration in durum wheat was lower when grown after canola than after flax, which could probably be due to reduction in mycorrhizal colonization (Grant et al. 2010).

\subsection{Tillage}

Rice production on aerobic soils often uses conventional full tillage of aerated soil (Bouman et al. 2007). In contrast, resource-conserving technologies using reduced or zero tillage are normally applied in the traditional lowland ricewheat system in south Asia (Jat et al. 2009). This difference in tillage management may have an impact on $\mathrm{pH}$ and nutrient stratification in the soil profile (Grant and Bailey 1994), and consequently affect bioavailability of $\mathrm{Zn}$. Studies on the influence of tillage on $\mathrm{Zn}$ availability are relatively rare and results are inconsistent. Franzluebbers and Hons (1996) reported that soil under a no-tillage system contained greater amounts of extractable $\mathrm{P}, \mathrm{K}$, and $\mathrm{Zn}$ than under a conventional tillage system. In contrast, long-term tillage did not affect total extractable $\mathrm{Zn}$ in a silty clay loam soil in the USA (Hickman 2002). Mahler et al. (1985) found that 10 years of continuous tillage did not affect soil DTPA-extractable Zn concentration. Studies by others (Shuman and McCracken 1999; Gao et al. 2010a; Grant et al. 2010) also confirmed the limited effect of tillage on $\mathrm{Zn}$ availability in soils and $\mathrm{Zn}$ levels in crops. Although this has not been specifically reported for aerobic rice, there is not much evidence from other crops that tillage will play a role in $\mathrm{Zn}$ nutrition of aerobic rice.

\section{Possible breeding targets}

The newly developed aerobic rice varieties combine some of the yield potential-enhancing traits of lowland variety and high drought tolerance of upland rice. In the context of $\mathrm{Zn}$, the genotypic variation in tolerance to low $\mathrm{Zn}$ soils and grain $\mathrm{Zn}$ concentration indicates that breeding can be a tool 
to cope with the wide-spread $\mathrm{Zn}$ deficiency in crop and humans. Therefore, combination of high tolerance to drought and $\mathrm{Zn}$ deficiency stress with high grain micronutrient concentration is desirable.

Maintaining good root growth is particularly important for acquisition of water and nutrients. Rice cultivars, including aerobic and lowland cultivars, differ in root morphology and architecture (Gao et al. 2005; Matsuo et al. 2009). The cultivars with longer and thinner roots and a greater proportion of thinner roots tend to be more tolerant to low $\mathrm{Zn}$ soils and should be included in the breeding strategies. In a pot study with 15 aerobic rice genotypes, a positive correlation existed between root surface area or root length and plant $\mathrm{Zn}$ uptake (Gao et al. 2005). In another pot study with two rice lines with contrasting $\mathrm{Zn}$ biomass efficiency, Widodo et al. (2010) found that Zn biomass efficiency was primarily associated with the capacity to maintain root growth and increased efflux of organic acids, rather than with increased Zn-transporter activity. Similar results were also reported in wheat (Dong et al. 1995). So far, studies on interaction of nutrient uptake and genotypic differences in root system architecture under field conditions are few. More research on the effect of the morphological and physiological changes in rice root traits under aerobic conditions on nutrient uptake is needed.

In developing high $\mathrm{Zn}$-dense rice varieties, the physiological mechanisms regulating uptake and allocation of $\mathrm{Zn}$ into grain should be carefully addressed as a breeding target. Root exudation of organic compounds into the rhizosphere is one of the important determinants of $\mathrm{Zn}$ uptake by aerobic rice (Gao et al. 2009). Root-shoot translocation of $\mathrm{Zn}$ (Palmgren et al. 2008), grain filling and stem-panicle transfer (Jiang et al. 2008a; Stomph et al. 2009), as well as the direct allocation of $\mathrm{Zn}$ from uptake during flowering (Jiang et al. 2007) can be addressed to provide better breeding targets. In a field study on a low $\mathrm{Zn}$ soil, Zn harvest index ranged between $33 \%$ and $47 \%$ for six rice genotypes(Gao et al. 2006), suggesting that development of rice genotypes or varieties with a high $\mathrm{Zn}$ harvest index is a promising strategy.

While inoculation of mycorrhizas can increase $\mathrm{Zn}$ uptake in aerobic rice, a combination of maximum mycorrhizal responsiveness and most efficient $\mathrm{Zn}$ uptake capacity in one genotype seems unrealistic. A dominant focus on mycorrhizal responsiveness could then lead to selection of genotypes that are less able to cope with low soil nutrient levels when nonmycorrhizal (Gao et al. 2007).

\section{Concluding remarks}

The increasing shortage of irrigation water is encouraging the cultivation shift from flooded to aerobic rice production in a number of traditional rice growing areas. Adapted aerobic rice cultivars are developed for this cultivation system. On calcareous soils with relatively high $\mathrm{pH}$, the cultivation shift from flooded to aerobic conditions increases $\mathrm{Zn}$ deficiency problems. On acid soils, however, aerobic rice will likely be less prone to $\mathrm{Zn}$ deficiency. Dissolved organic anions, $\mathrm{pH}$, and redox conditions, which significantly differ between water regimes, are important factors determining $\mathrm{Zn}$ availability in soils. Plant factors such as root growth, mycorrhizal inoculation, and root release of organic compounds into rhizosphere can also have major effects. The consequence of a cultivation shift for $\mathrm{Zn}$ bioavailability is a function of the changes of all these factors. The relative importance of each factor will differ among soils and could be carefully evaluated by a biogeochemical modeling approach focused on the rhizosphere soils. An unbiased rhizosphere sampling, in combinations with the modeling approach, could lead to an improved understanding of the concept of $\mathrm{Zn}$ bioavailability.

There is considerably genotypic variation among both lowland and aerobic rice in tolerance to $\mathrm{Zn}$ deficiency. The variation in tolerance was mainly associated with plant $\mathrm{Zn}$ uptake, specifically related to exudation of organic compounds in the rhizosphere. Appropriate rhizosphere management has great potential to improve crop growth, as well as the micronutrient nutrition in crops, either through an increase in root exploration volume, i.e., root surface area and mycorrhizae, or through manipulation of the chemical conditions in the rhizosphere, i.e., acidification and release of phytosiderophores.

Adjustment in management practices such as fertilization, manure application, and more diversified aerobic ricebased cropping systems are needed to make the cultivation shift to aerobic rice production systems a sustainable one. The effects of new management practices on bioavailability of micronutrients, as well as their concentrations in the rice grain, should be better documented. Addition of $\mathrm{Zn}$ fertilizers by soil or foliar application have been shown to increase $\mathrm{Zn}$ concentration in cereal grains. The extent of increase, however, shows a great dependency on crop species. It is more difficult to increase $\mathrm{Zn}$ concentration through $\mathrm{Zn}$ fertilization in rice cultivars than in other cereal crops such as wheat and barley. An appropriate N management strategy has yet to be established but should carefully consider the effects on soil $\mathrm{pH}$ in selection of source, rate, application method, and timing of fertilizers. Application of $\mathrm{P}$ fertilizer should avoid creating an imbalance in $\mathrm{Zn}$ uptake as this could compromise both efficacy of the $\mathrm{P}$ fertilizer and decrease the nutritional quality of the grain produced. Cropping systems such as rotation and intercropping have potential to improve both grain yield and grain quality. Consecutive planting of rice on the same area should be avoided. Adoption of aerobic 
rice in the gramineous/dicot intercropping system can be an interesting research topic and may add new insights into biofortification.

\section{References}

Agbenin JO (1998) Phosphate-induced zinc retention in a tropical semi-arid soil. Eur J Soil Sci 49:693-700

Alloway BJ (ed) (2004) Zinc in soils and crop nutrition. International Zinc Association, Brussels

Alloway BJ (2009) Soil factors associated with zinc deficiency in crops and humans. Environ Geochem Health 31:537-548

Alok K, Yadav DS (1995) Use of organic manure and fertilizer in rice (Oryza sativa)-wheat (Triticum aestivum) cropping system for sustainability. Ind J Agric Sci 65:703-707

Arnold T, Kirk GJD, Wissuwa M, Frei M, Zhao FJ, Mason TFD, Weiss DJ (2010) Evidence for the mechanisms of zinc uptake by rice using isotope fractionation. Plant Cell Environ 33:380381

Arsenault JE, Yakes EA, Hossain MB, Islam MM, Ahmed T, Hotz C, Lewis B, Rahman AS, Jamil KM, Brown KH (2010) The current high prevalence of dietary zinc inadequacy among children and women in rural Bangladesh could be substantially ameliorated by zinc biofortification of rice. J Nutr 140:1683-1690

Belder P, Bouman BAM, Cabangon R, Lu G, Quilang EJP, Li Y, Spiertz JHJ, Tuong TP (2004) Effect of water-saving irrigation on rice yield and water use in typical lowland conditions in Asia. Agric Water Manage 65:193-210

Benke MB, Indraratne SP, Hao XY, Chang C, Goh TB (2008) Trace element changes in soil after long-term cattle manure applications. J Environ Qual 37:798-807

Bostick BC, Hansel CM, La Force MJ, Fendorf S (2001) Seasonal fluctuations in zinc speciation within a contaminated wetland. Environ Sci Technol 35:3823-3829

Bouman BAM, Humphreys E, Tuong TP, Barker R (2007) Rice and water. Adv Agron 92:187-237

Broadbent FE, Mikkelsen DS (1968) Influence of placement on uptake of tagged nitrogen by rice. Agron J 60:674-677

Cakmak I (2008) Enrichment of cereal grains with zinc: agronomic or genetic biofortification? Plant Soil 302:1-17

Cakmak I, Gulut KY, Marschner H, Graham RD (1994) Effect of zinc and iron deficiency on phytosiderophore release in wheat genotypes differing in zinc deficiency. J Plant Nutr 17:1-17

Cakmak I, Torun A, Millet E, Feldman M, Fahima T, Korol A, Nevo E, Braun HJ, Ozkan H (2004) Triticum dicoccoides: an important genetic resource for increasing zinc and iron concentration in modern cultivated wheat. Soil Sci Plant Nutr 50:1047-1054

Cakmak I, Pfeiffer WH, McClafferty B (2010) Biofortification of durum wheat with zinc and iron. Cereal Chem 87:10-20

Carbonell-Barrachina AA, Jugsujinda A, Burlo F, Delaune RD, Patrick WH (2000) Arsenic chemistry in municipal sewage sludge as affected by redox potential and $\mathrm{pH}$. Water Res 34:216-224

Cavagnaro TR (2008) The role of arbuscular mycorrhzas in improving plant zinc nutrition under low soil zinc concentrations: a review. Plant Soil 304:315-325

Cavagnaro TR, Dickson S, Smith FA (2010) Arbuscular mycorrhizas modify plant responses to soil zinc addition. Plant Soil 329:307313

Chen XP, Kong WD, He JZ, Liu WJ, Smith SE, Smith FA, Zhu YG (2008) Do water regimes affect iron-plaque formation and microbial communities in the rhizosphere of paddy rice? J Plant Nutr Soil Sci 171:193-199
Chen WR, He ZL, Yang XE, Feng Y (2009) Zinc efficiency is correlated with root morphology, ultrastructure, and antioxidative enzymes in rice. J Plant Nutr 32:287-305

Dobermann A, Fairhust T (2000) Rice: nutrient disorders and nutrient management IRRI. Makati City, Philippines

Dong B, Rengel Z, Graham ED (1995) Root morphology of wheat genotypes differing in zinc efficiency. J Plant Nutr 18:2761-2773

Drew MC, Saker LR (1975) Nutrient supply and the growth of the seminal root system in barley: II. Localized, compensatory increases in lateral root growth and rates op nitrate uptake when nitrate supply is restricted to only part of the root system. J Exp Bot 26:79-90

Drew MC, Saker LR (1978) Nutrient supply and the growth of the seminal root system in barley: III. Compensatory increases in growth of lateral roots, and in rates of phosphate uptake, in response to a localized supply of phosphate. J Exp Bot 29:435451

Egrinya EA, Yamamoto S, Honna T (2001) Rice growth and nutrient uptake as affected by livestock manure in four Japanese soils. J Plant Nutr 24:333-343

Erenoglu EB, Kutman UB, Ceylan Y, Yildiz B, Cakmak I (2011) Improved nitrogen nutrition enhances root uptake, root-to-shoot translocation and remobilization of zinc $\left({ }^{65} \mathrm{Zn}\right)$ in wheat. New Phytol 189:438-448

Fageria NK (2000) Upland rice response to soil acidity in Cerrado soil. [Portuguese]. Pesquisa Agropecuaria Brasileira 35:23032307

Fageria NK, Filho MPB (2007) Dry-matter and grain yield, nutrient uptake, and phosphorus use-efficiency of lowland rice as influenced by phosphorus fertilization. Comm Soil Sci Plant Anal 38:1289-1297

Forde B, Lorenzo H (2001) The nutritional control of root development. Plant Soil 232:51-68

Franzluebbers AJ, Hons FM (1996) Soil-profile distribution of primary and secondary plant-available nutrients under conventional and no tillage. Soil Till Res 39:229-239

Gao S, Tanji KK, Scardaci SC, Chow AT (2002) Comparison of redox indicators in a paddy soil during rice-growing season. Soil Sci Soc Am J 66:805-817

Gao X, Zou C, Zhang F, van der Zee SEATM, Hoffland E (2005) Tolerance to zinc deficiency in rice correlates with zinc uptake and translocation. Plant Soil 278:253-261

Gao X, Zou C, Fan X, Zhang F, Hoffland E (2006) From flooded to aerobic conditions in rice cultivation: consequences for zinc uptake. Plant Soil 280:41-47

Gao X, Kuyper TW, Zou C, Zhang F, Hoffland E (2007) Mycorrhizal responsiveness of aerobic rice genotypes is negatively correlated with their zinc uptake when nonmycorrhizal. Plant Soil 290:283291

Gao X, Zhang F, Hoffland E (2009) Malate exudation by six aerobic rice genotypes varying in zinc uptake efficiency. J Environ Qual 38:2315-2321

Gao X, Akhter F, Tenuta M, Flaten DN, Gawalko EJ, Grant CA (2010a) Mycorrhizal colonization and grain Cd concentration of field-grown durum wheat in response to tillage, preceding crop and phosphorus fertilization. J Sci Food Agric 90:750-758

Gao X, Brown KR, Racz GJ, Grant CA (2010b) Concentration of cadmium in durum wheat as affected by time, source and placement of nitrogen fertilization under reduced and conventional-tillage management. Plant Soil 337:341-354

Gao X, Schröder TJ, Hoffland E, Zou C, Zhang F, van der Zee SEATM (2010c) Geochemical modeling of zinc bioavailability for rice. Soil Sci Soc Am J 74:301-309

Genc Y, McDonald GK, Graham RD (2004) Differential expression of zinc efficiency during the growing season of barley. Plant Soil 263:273-282 
Genc Y, McDonald GK, Graham RD (2006) Contribution of different mechanisms to zinc efficiency in bread wheat during early vegetative stage. Plant Soil 281:353-367

Giordano PM (1979) Soil temperature and nitrogen effects on response of flooded and nonflooded rice to zinc. Plant Soil 52:365-372

Giordano PM, Mortvedt JJ (1974) Response of several rice cultivars to Zn. Agron J 66:220-223

Graham RD, Welch RM, Saunders DA, Ortiz-Monasterio I, Bouis HE, Bonierbale M, de Haan S, Burgos G, Thiele G, Liria R, Meisner CA, Beebe SE, Potts MJ, Kadian M, Hobbs PR, Gupta RK, Twomlow S (2007) Nutritious subsistence food systems. Adv Agron 92:1-74

Grant CA, Bailey LD (1994) The effect of tillage and $\mathrm{KCl}$ addition on $\mathrm{pH}$, conductance, $\mathrm{NO} 3-\mathrm{N}, \mathrm{P}, \mathrm{K}$ and $\mathrm{Cl}$ distribution in the soil profile. Can J Soil Sci 74:307-314

Grant CA, Bailey LD, Harapiak JT, Flore NA (2002) Effect of phosphate source, rate and cadmium content and use of Penicillium bilaii on phosphorus, zinc and cadmium concentration in durum wheat grain. J Sci Food Agr 82:301-308

Grant CA, Monreal MA, Irvine RB, Mohr RM, Mclaren DL (2010) Preceding crop and phosphorus fertilization affect cadmium and zinc concentration of flaxseed under conventional and reduced tillage. Plant Soil 333:337-350

Gunes A, Inal A, Adak MS, Alpaslan M, Bagci EG, Erol T, Pilbeam DJ (2007) Mineral nutrition of wheat, chickpea and lentil as affected by intercropped cropping and soil moisture. Nutr Cycl Agroecosyst 78:83-96

Gupta VK, Singh CP, Relan PS (1992) Effect of Zn-enriched organic manures on $\mathrm{Zn}$ nutrition of wheat and residual effect on soybean. Bioresource Technol 42:155-157

Hacisalihoglu G, Ozturk L, Cakmak I, Welch RM, Kochian L (2004) Genotypic variation in common bean in response to zinc deficiency in calcareous soil. Plant Soil 259:71-83

Hajiboland R, Yang XE, Römheld V, Neumann G (2005) Effect of bicarbonate on elongation and distribution of organic acids in root and root zone of $\mathrm{Zn}$-efficient and $\mathrm{Zn}$-inefficient rice (Oryza sativa L.) genotypes. Environ Exp Bot 54:163-173

Hajiboland R, Aliasqharzad N, Barzeqhar R (2009) Phosphorus mobilization and uptake in mycorrhizal rice (Oryza sativa L.) plants under flooded and non-flooded conditions. Acta Agr Slov 93:153-161

Haldar M, Mandal LN (1981) Effect of phosphorus and zinc on the growth and phosphorus, zinc, copper, iron and manganese nutrition of rice. Plant Soil 59:415-425

Harris D, Rashid A, Miraj G, Arif M, Shah H (2007) Priming seeds with zinc sulphate solution increases yields of maize (Zea mays L.) on zinc-deficient soils. Field Crops Res 102:119-127

Hickman MV (2002) Long-term tillage and crop rotation effects on soil chemical and mineral properties. J Plant Nutr 25:1457-1470

Hoffland E, Wei C, Wissuwa M (2006) Organic anion exudation by lowland rice (Oryza sativa L.) at zinc and phosphorus deficiency. Plant Soil 283:155-162

Holloway RE, Graham RD, McBeath TM, Brace DM (2010) The use of a zinc-efficient wheat cultivar as an adaptation to calcareous subsoil: a glasshouse study. Plant Soil 336:15-24

Hotz C (2009) The potential to improve zinc status through biofortification of staple food crops with zinc. Food Nutr Bull 30:S172-S178

Inal A, Gunes A (2008) Interspecific root interactions and rhizosphere effects on salt ions and nutrient uptake between mixed grown peanut/maize and peanut/barley in original saline-sodic-boron-toxic soil. J Plant Physiol 165:490-503

Inal A, Gunes A, Zhang FS, Cakmak I (2007) Peanut/maize intercropping induced changes in rhizosphere and nutrient concentrations in shoots. Plant Physiol Bioch 45:350-356
Inoue H, Kobayashi T, Nozoye T, Takahashi M, Kakei Y, Suzuki K, Nakazono M, Nakanishi H, Mori S, Nishizawa NK (2009) Rice OsYSL15 is an iron-regulated iron(III)-deoxymugineic acid transporter expressed in the roots and is essential for iron uptake in early growth of the seedlings. J Biol Chem 284:3470-3479

International Rice Research Institute (IRRI) (1997) Rice almanac, 2nd edn. IRRI, Los Baños

Ismail AM, Heuer S, Thomson MJ, Wissuwa M (2007) Genetic and genomic approaches to develop rice germplasm for problem soils. Plant Mol Biol 65:547-570

Jat ML, Gathala MK, Ladha JK, Saharawat YS, Jat AS, Vipin K, Sharma SK, Kumar V, Raj G (2009) Evaluation of precision land leveling and double zero-till systems in the rice-wheat rotation: water use, productivity, profitability and soil physical properties. Soil Till Res 105:112-121

Jiang W, Struik PC, Liang J, van Keulen H, Zhao M, Stomph TJ (2007) Uptake and distribution of root applied or foliar-applied ${ }^{65} \mathrm{Zn}$ after flowering in aerobic rice. Ann Appl Biol 150:383-391

Jiang W, Struik PC, van Keulen H, Zhao M, Jin LN, Stomph TJ (2008a) Does increased zinc uptake enhance grain zinc mass concentration in rice? Ann Appl Biol 153:135-147

Jiang W, Struik PC, Zhao M, Van Keulen H, Fan TQ, Stomph TJ (2008b) Indices to screen for grain yield and grain zinc mass concentrations in aerobic rice at different soil-Zn levels. NJASWageningen J Life Sci 55:181-197

Johnson-Beebout SE, Lauren JG, Duxbury JM (2009) Immobilization of zinc fertilizer in flooded soils monitored by adapted DTPA soil test. Comm Soil Sci Plant Anal 40:1842-1861

Kato Y, Henry A, Fujita D, Katsura K, Kobayashi N, Serraj R (2011) Physiological characterization of introgression lines derived from an indica rice cultivar, IR64, adapted to drought and water-saving irrigation. Field Crops Res 123:130-138

Khan HR, McDonald GK, Rengel Z (1998) Chickpea genotypes differ in their sensitivity to Zn deficiency. Plant Soil 198:11-18

Khoshgoftarmanesh AH, Chaney RL (2007) Preceding affects cadmium and zinc of wheat grown in saline soils of central Iran. J Environ Qual 36:1132-1136

Kirk GJD, Bajita JB (1995) Root-induced iron oxidation, $\mathrm{pH}$ changes and zinc solubilization in the rhizosphere of lowland rice. New Phytol 131:129-137

Kirk GJD, Saleque MA (1995) Solubilization of phosphate by rice plants growing in reduced soil: prediction of the amount solubilized and the resultant increase in uptake. Eur J Soil Sci 46:247-255

Kutman UB, Yildiz B, Ozturk L, Cakmak I (2010) Biofortification of durum wheat with zinc through soil and foliar applications of nitrogen. Cereal Chem 87:1-9

Lindsay, WL (1972) Inorganic phase equilibria of micronutrients in soils. In: Mortvedt, JJ, Giordano, PM, Lindsay, WL (Eds) Micronutrients in Agriculture. pp. 41-57

Mahler RL, Hammel JE, Harder RW (1985) The influence of crop rotation and tillage methods on DTPA-extractable copper, iron, manganese, and zinc in northern Idaho soils. Soil Sci 139:279286

Mandal B, Hazra GC, Mandal LN (2000) Soil management influences on zinc desorption for rice and maize nutrition. Soil Sci Soc Am J 64:1699-1705

Maret W, Sandstead HH (2006) Zinc requirements and the risks and benefits of zinc supplementation. J Trace Elem Med Biol 20:3-18

Marschner H (ed) (1995) Mineral nutrition of higher plants. Academic, London, p 889

Matsuo N, Ozawa K, Mochizuki T (2009) Genotypic differences in root hydraulic conductance of rice (Oryza sativa L.) in response to water regimes. Plant Soil 316:25-34

Matsuo N, Ozawa K, Mochizuki T (2010) Physiological and morphological traits related to water use by three rice (Oryza 
sativa L.) genotypes grown under aerobic rice systems. Plant Soil 335:349-361

Mengel K, Kirkby EA (eds) (1987) Principles of plant nutrition, 4th edn. IPI, Bern, p 594

Moraghan T, Sims A, Smith L (1999) Zinc in wheat grain as affected by nitrogen fertilization and available soil zinc. J Plant Nutr 22:709-716

Olsen SR (1972) Micronutrient interaction. In Micronutrients in Agriculture. Soil Sci. Society of America. Inc, Wisconsin, pp 243-264

Palmgren MG, Clemens S, Williams LE, Krämer U, Borg S, Schjørring JK, Sanders D (2008) Zinc biofortification of cereals: problems and solutions. Trends Plant Sci 13:464-473

Pinheiro BDS, Castro EDMD, Guimarães CM (2006) Sustainability and profitability of aerobic rice production in Brazil. Field Crops Res 97:34-42

Ponnamperuma F.N. (1972) (Ed) The chemistry of submerged soils, pp. 29-96

Purakayastha TJ, Chhonkar PK (2001) Influence of vesiculararbuscular mycorrhizal fungi (Glomus etunicatum L.) on mobilization of zinc in wetland rice (Oryza sativa L.). Biol Fert Soil 33:323-327

Ramani S, Kannan S (1985) An examination of zinc uptake patterns by cultivars of sorghum and maize: differences amongst hybrids and their parents. J Plant Nutr 8:1199-1210

Ren L, Su S, yang X, Xu Y, Huang Q, Shen Q (2008) Intercropping with aerobic rice suppressed Fusarium wilt in watermelon. Soil Biol Biochem 40:834-844

Rose MT, Rose TJ, Tanaka JP, Widodo JA, Wissuwa M (2011) Revisiting the role of organic acids in the bicarbonate tolerance of zinc-efficient rice genotypes. Funct Plant Biol 38:493-504

Ryan MH, Angus JF (2003) Arbuscular mycorrhizae in wheat and field pea crops on a low P soil: increased Zn-uptake but no increase in P-uptake or yield. Plant Soil 250:225-239

Ryan MH, McInerney JK, Record JR, Angus JF (2008) Zinc bioavailability in wheat grain in relation to phosphorus fertiliser, crop sequence and mycorrhizal fungi. J Sci Food Agr 88:1208-1216

Sajwan KS (1985) Zinc nutrition and redox relationships of submerged paddy rice. Dissertation Abstracts International B (Sciences and Engineering) 46:1754B

Shen Q, Chu G (2004) Bi-directional nitrogen transfer in an intercropping system of peanut with rice cultivated in aerobic soil. Biol Fert Soils 40:81-87

Shi RL, Zhang YQ, Chen XP, Sun QP, Zhang FS, Römheld V, Zou CQ (2010) Influence of long-term nitrogen fertilization on micronutrient density in grain of winter wheat (Triticum aestivum L.). J Cereal Sci 51:165-170

Shuman LM, McCracken DV (1999) Tillage, lime, and poultry litter effects on soil zinc, manganese, and copper. Comm Soil Sci Plant Anal 30:1267-1277

Srivastava PC, Ghosh D, Singh VP (1999) Evaluation of different zinc source for lowland rice production. Biol Fert Soil 30:168-172

Stomph TJ, Jiang W, Struik PC (2009) Zinc biofortification of cereals: rice differs from wheat and barley. Trends Plant Sci 14:123-124

Suzuki M, Takahashi M, Tsukamoto T, Watanabe S, Matsuhashi S, Yazaki J, Kishimoto N, Kituchi S, Nakanishi H, Mori S, Nishizawa NK (2006) Biosynthesis and secretion of mugineic acid family phytosiderophores in zinc-deficient barley. Plant $\mathrm{J}$ 48:85-97

Suzuki M, Tsukamoto $\mathrm{T}$, Inoue $\mathrm{H}$, Watanabe $\mathrm{S}$, Matsuhashi $\mathrm{S}$, Takahashi M, Nakanishi H, Mori S, Nishizawa NK (2008) Deoxymugineic acid increases $\mathrm{Zn}$ translocation in Zn-deficient rice plants. Plant Mol Biol 66:609-617

Takagi S (1976) Naturally occurring iron-chelating compounds in oatand rice-root washings. I. Activity measurement and preliminary characterization. Soil Sci Plant Nutr 22:423-433
Turmel MS, Entz MH, Bamford KC, Martens JRT (2009) The influence of crop rotation on the mineral nutrient content of organic vs. conventionally produced wheat grain: preliminary results from a long-term field study. Can J Plant Sci 89:915919

Verna TS, Minhas RS (1987) Zinc and phosphorus interaction in a wheat-maize cropping system. Fert Res 13:77-86

Walter A, Römheld V, Marschner H, Mori S (1994) Is the release of phytosiderophores in zinc-deficient wheat plants a response to impaired iron utilization? Physiol Plantarum 92:493-500

Wang HQ, Bouman BAM, Zhao D, Wang C, Moya PE (2002) Aerobic rice in northern China: opportunities and challenges. In: Bouman BAM, Hengsdijk H, Hardy B, Bindraban PS, Tuong TP, Ladha JK (eds) Water-Wise Rice Production. International Rice Research Institute, Los Baños, pp 143-154

Wellings NP, Wearing AH, Thompson JP (1991) Vesiculararbuscular mycorrhizae (VAM) improve phosphorus and zinc nutrition and growth of pigeonpea in a Vertisol. Aus J Agr Res 42:835-845

Whiting SN, Leake JR, McGrath SP, Baker AJM (2000) Positive responses to $\mathrm{Zn}$ and $\mathrm{Cd}$ by roots of the $\mathrm{Zn}$ and $\mathrm{Cd}$ hyperaccumulator Thlaspi caerulescens. New Phytol 145:199210

Widodo BMR, Rose T, Frei M, Pariasca-Tanaka J, Yoshihashi T, Thomson M, Hammond JP, Aprile A, Close TJ, Ismail A, Wissuwa M (2010) Response to zinc deficiency of two rice lines with contrasting tolerance is determined by root growth maintenance and organic acid exudation rates, and not by zinctransporter activity. New Phytol 186:400-414

Wissuwa M, Ismail AM, Yanagihara S (2006) Effects of zinc deficiency on rice growth and genetic factors contributing to tolerance. Plant Physiol 142:731-741

Wissuwa M, Ismail AM, Graham RD (2007) Rice grain zinc concentrations as affected by genotype, native soil-zinc, and zinc fertilization. Plant Soil 306:37-48

Wu CY, Lu LL, Yang XE, Feng Y, Wei YY, Hao HL, Stoffella PJ, He ZL (2010) Uptake, translocation, and remobilization of zinc absorbed at different growth stages by rice genotypes of different Zn densities. J Agric Food Chem 58:6767-6773

Yadvinder S, Dobermann A, Bijay-Singh BKF, Khind CS (2000) Optimal phosphorus management strategies for wheat-rice cropping on a loamy sand. Soil Sci Soc Am J 64:14131422

Yang X, Romheld V, Marschner H (1994) Effect of bicarbonate on root growth and accumulation of organic acids in $\mathrm{Zn}$ inefficient and Zn-efficient rice cultivars (Oryza sativa L.). Plant Soil 164:1-7

Yang X, Hajiboland R, Römheld V (2003) Bicarbonate had greater effects than high $\mathrm{pH}$ on inhibiting root growth of zinc-inefficient rice genotype. J Plant Nutr 26:399-415

Yang X, Bouman BAM, Wang H, Wang Z, Zhao J, Chen B (2005) Performance of temperate aerobic rice under different water regimes in North China. Agric Water Manage 74:107-122

Yilmaz A, Ekiz H, Torun B, Gultekin I, Karanlik S, Bagci SA, Cakmak I (1997) Effect of different zinc application methods on grain yield and zinc concentration in wheat cultivars grown on zinc deficient calcareous soils. J Plant Nutr 20:461-471

Yoshida S (ed) (1981) Fundamentals of rice crop science. IRRI, Los Banos, p 269

Yoshida S, Forno DA, Bhadrachalam A (1971) Zinc deficiency of the rice plant on calcareous and neutral soils in the Philippines. Soil Plant Food 17:83-87

Zhang H, Jennings A, Peter WB, Brian GF (1999) Dual pathways for regulation of root branching by nitrate. Plant Biol 96:529-534 
Zhang J, Wu LH, Wang MY (2008) Iron and zinc biofortification in polished rice and accumulation in rice plant (Oryza sativa L.) as affected by nitrogen fertilization. Acta Agricul Scand B 58:267272

Zhang F, Shen J, Zhang J, Zuo Y, Li L, Chen X (2010) Rhizosphere processes and management for improving nutrient use efficiency and crop productivity: implications for China. Adv Agron 107:1-32
Zuo Y, Zhang F (2008) Effect of peanut mixed cropping with gramineous species on micronutrient concentrations and iron chlorosis of peanut plants grown in a calcareous soil. Plant Soil 306:23-36

Zuo Y, Zhang F (2009) Iron and zinc biofortification strategies in dicot plants by intercropping with gramineous species. A review. Agron Sustain Dev 29:63-71 